\section{ESTUDO SOBRE O USO DE MOSQUITEIROS IMPREGNADOS COM DELTAMETRINA EM UMA ÁREA ENDÊMICA DE MALÁRIA NA AMAZÔNIA BRASILEIRA}

\begin{abstract}
Uma investigação sobre mosquiteiros impregnados com deltametrina foi efetuada no município de Costa Marques, Rondônia, em 1992. Em fevereiro de 1992, em um grupo de 20 moradias na localidade de Porto Murtinho, situada à márgem direita do rio São Miguel, foram instalados mosquiteiros impregnados e, em outro grupo de 20 casas, na mesma localidade, mosquiteiros não impregnados. Um grupo controle de 20 residências, sem usar mosquiteiros de qualquer tipo, foi escolhido na localiciade de Aguas Francas, às márgens da BR-429, que liga Costa Marques a Presidente Medici, Rondônia.
\end{abstract}

Os mosquiteiros fechados, de pano de algodão, foram impregnados pelo método de borrifação, ou "spray", com deltametrina, na dosagem de $20 \mathrm{mg} / \mathrm{m}^{2}$.

Após distribuídos os mosquiteiros em fevereiro de 1992, foram feitas revisôes clínicas, parasitológicas e entomológicas, a cada dois meses, até fevereiro de 1993, completando um ano de observação. Os resultados dessas revisões pósintervenção foram comparados com a situação pré-intervenção em cada grupo e, entre os grupos de mosquiteiros impregnados e de não impregnados.

Os mosquiteiros impregnados se comportaram de modo semelhante aos não impregnados, sem modificar os índices de infecção na época de baixa transmissão. A análise multivariada, por idade e títulos de anticorpos, mostrou uma proteção significantemente maior para o grupo com mosquiteiros impregnados contra o risco de infecção, apenas na estação de alta transmissão, quando os mosquiteiros foram usados mais regularmente. Não houve diferença no efeito de ambos os tipos de mosquiteiros na prevenção de elevadas parasitemias. A redução da prevalência de malária em Porto Murtinho em 1992, comparada ao ano anterior, reflete a diminuição progressiva dos índices malariométricos 'em Rondônia e em Costa Marques, desde 1987.

\section{A STUDY OF DELTAMETHRIN IMPREGNATED MOSQUITO BED NETS IN A MALARLA ENDEMIC AREA OF THE BRAZILIAN AMAZON}

In 1992 an investigation regarding the value of insecticide impregnated mosquito bed nets was conducted in the municipality of Costa Marques, Rondonia. In February in a group of 20 houses in Porto Murtinho on the right bank of the river São Miguel, impregnated mosquito bed nets were installed and in a further similar group unimpregnated nets were used as control. A further 20 houses acted as second control where no mosquito bed nets were used in the community of Águas Francas, on the margin of BR- 429 which links Costa Marques with the town of Presidente Medici.

The mosquito nets were of the closed type using cotton sheets impregnated by spraying with $20 \mathrm{mg} / \mathrm{m}^{2}$ of deltamethrin.

After the installation of the project in February 1992 clinical, parasitological and entomological evaluations continued bi-monthly for a year. The results were compared with the situation before the control intervention.

Impregnated mosquito bed nets gave similar protection to those not impregnated, without modifying the incidence of infection during the season of low transmission. The multivaried analysis for age and antibodies title showed a significant protection of impregnated nets against the risk of infection only in the season of high transmission, when bed nets were used more correctly. There was no difference in the effect of both kinds of bed nets in the prevention of high parasitaemia. A reduction in malaria prevalence in Porto Murtinho in 1992 compared with the previous year reflects the progressive diminuition of malariometric indices in Rondonia and Costa Marques since 1987.

At the end of the study, there was a reduction of splenomegaly in both groups with bed nets. The use of impregnated nets reduced the incidence of splenomegaly in subjects above 5 years of age, but decrease of spleen size occured 
Resumo de Tese. LSantos JB. Estudo sobre o uso de mosquiteiros impregnados com deltametrina em uma área endêmica de maläria na Amazônia Brasileira. Revista da Sociedade Brasileira de Medicina Tropical 29:513514, set-out, 1996.

Ao fim do estudo, houve diminuição da prevalência de esplenomegalia em ambos os grupos com mosquiteiros. O uso de mosquiteiros impregnados diminuiu especificamente a prevalência de esplenomegalia em maiores de 5 anos de idade, mas a regressão de esplenomegalia só foi observada em pessoas acima de 15 anos, a faixa etária menos acometida pela doença na época de alta transmissão, apesar de ter sido a que menos fez uso regular dos mosquiteiros. Houve recuperação da taxa normal de hematócrito em menores de 15 anos, com mosquiteiros impregnados.

O uso de mosquiteiros impregnados ou de não impregnados não modificou a frequência de soropositivos, nem causou uma diferença na diminuição dos títulos de anticorpos contra formas assexuadas do Plasmodium falciparum ao teste da IFI.

Os mosquiteiros impregnados diminuíram a densidade vetorial no intradomicílio nos períodos de baixa densidade anofélica na região. O efeito foi marcante contra o Anopheles darlingi, cuja taxa de captura diminuiu no espaço intradomiciliar em todas as épocas do ano, no curso da pesquisa. Não houve modificação da maior densidade vetorial no peridomicílio.

$O$ efeito inseticida sobre a mortalidade de mosquitos foi maior sobre o Anopheles deaneorum, que foi a espécie mais capturada no intradomicilio, seguida pelo Anopheles darlingi, que foi a espécie mais capturada no peridomicílio.

Os mosquiteiros impregnados determinaram diminuição da densidade vetorial intradomiciliar porém, sem causar grande impacto sobre a morbidade da malária em Porto Murtinho. Embora o uso tenha sido muito irregular na estação seca, os mosquiteiros impregnados tiveram excelente aceitação pela populaçâo contudo, o seu preço factível de ser encarecido pelas dificuldades regionais, poderá torná-los inacessiveis à capacidade aquisitiva da população local. only in subjects above 15 of age. This age group was less diseased in the high transmission season even although they did not always use the nets correctly. Hematocrits values rose to normal in the below 15 years olds using impregnated nets.

The use of impregnated or none impregnated nets did not modify the seropositive rates or cause a differential reduction in the fluorescent antibodies title in any group.

The impregnated nets diminished the intradomiciliary vector density during the period of low anopheline density. The effect was most marked for Anopheles darlingi only low numbers being captured throughout the year of observation. There was no change in the vector density in the peridomicile.

The insecticide effect was most marked against Anopheles deaneorum which was the species most commonly found in the house while Anopbeles darlingi was most frequent in the peridomicile.

Impregnated mosquito nets influenced vectorial density inside the house but not to the extent of significantly affecting the epidemiological indices of human malaria in Porto Murtinho. Although the irregular use during the dry season, mosquito nets were well accepted by the population. Cost meant that the majority of the population could not affored to buy such a luxury.

\section{Joâo Barberino Santos}

Tese apresentada à Faculdade de Medicina da Universidade Federal de Minas Gerais para obtenção do Título de Doutor. Belo Horizonte, MG, Brasil, 1995. 